\title{
Research on the Status and Application Effect of Online Web Course Platform
}

\author{
Yuxia Zhong ${ }^{1, a}$, Mo Liu' ${ }^{2, b^{*}}$ and Zhifeng Yin ${ }^{3, b}$ \\ ${ }^{1}$ Aotomotive and Architectural Engineering Institute, Beihua University, China, 130021 \\ ${ }^{2}$ Aotomotive and Architectural Engineering Institute, Beihua University, China, 130021 \\ ${ }^{3}$ Railway Engineering Department, Jilin Railway Technical College, China,132200

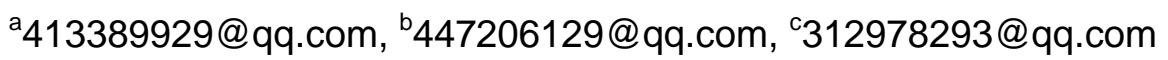 \\ * The Corresponding Author
}

Keywords: Network teaching; Current status; Application effect

\begin{abstract}
The paper analyzes the status of network teaching in combination with the mode of information teaching of universities in China. Take the school as an example, the application effect of web courses is analyzed, and it is proposed that we should stimulate teachers' enthusiasm for investment and guidance of students' learning methods from the perspective of policy guidance, professional demonstration, curriculum integration, and learning effect radiation. The marginal disadvantage of online teaching is changed gradually, and the normal network teaching environment is formed.
\end{abstract}

\section{Introduction}

The network teaching platform is a computer network system [1] that has a series of functions, such as organizing, tracking, evaluating, sending, presenting, managing learning contents and learning activities, facilitating interaction between learners. Many online teaching platform software has been developed at home and abroad, such as Black Board, Moodle and Sakai abroad, domestic self-developed "Curriculum Center", "sky classroom", "Tsinghua Education Online", "4A" ,etc.[2]. The Ministry of Education launched online boutique open courses construction to promote the popularization of digital information technology, Online network teaching is used as an aid to traditional teaching. In fact, various digital teaching achievements in online teaching and development have not been effectively used, and online teaching is still on the verge. situation.

\section{Developing the Status of Online Teaching}

Teachers are the core of online education to overcome various problems in teaching reform. Among the factors that hinder university teachers from developing online education, time/energy, policy/training/support and platform issues are among the top 3 [3]. Most teachers are based on quality course construction, teaching tasks, teaching evaluation, etc. to carry out online course research, compared to the traditional to invest 2 to 3 times the time and experience. How to stimulate the enthusiasm of teachers to continue to carry out curriculum research and construction is of utmost importance.

Colleges do not have incentive policies for teachers engaged in network teaching. The balance of the final evaluation of the local colleges with applied talents tends to be scientific research. This will inevitably lead to the inability and advancement of network teaching, and the formation of the edge of traditional teaching. How to set policies to guide the normal development of network education has become an urgent problem for university management.

In response to the problems existing in universities, and combining with the specific implementation process of our university, we propose strategies for the promotion of online teaching in order to provide reference for similar universities . 


\section{University Policy Innovation Guidance is the Source of Online Teaching Promotion}

Our school uses the Tsinghua Education Online Network Teaching Platform. In order to motivate the enthusiasm of teachers' online course construction and development, we adopt a semi-mandatory promotion policy of "gradient promotion, project guidance, and job title binding". At the same time, with the guidance of high-quality demonstration course construction projects, we will carry out three-year 300-course construction plans. In 2016, it was formally incorporated into the title evaluation system. In the past three years, we have built 3081 network platform courses in 83 professions with a total of 1.6 million visitors.

In 2013, the school began to promote the establishment of online courses in various institute. Only 22 institutes of the university participated in the establishment of 100 courses; the school started the second phase of the network course in 2016, and the number of institute reached 26. Institutes such as the Institute of Electrical and Information Engineering, the Institute of Automotive Engineering, and the Institute of Mechanical Engineering can increase the number of courses by three times. The Institute of Electrical Engineering is ranked top of the school Top 15 list, and the amount of annual development courses reaches 20. The first institute to be developed includes Preschool Education Design and Guidance for Kindergarten Education, Chao Chen 's "Literature Search", and Meng Yu 's "Primary Three Oral Lessons for Foreigners" in International Exchange Academy. It can be seen that local universities attach great importance to the guideline of online teaching innovation policy, and the higher the enthusiasm of teachers in their attempt to develop online teaching is higher.

\section{Online Professional Course Platform Construction is Conducive to Promoting the Integration of Curriculum System}

Professional courses are homogeneous, and the establishment of an online course platform within the institute can enhance professional ability of schools. The civil engineering major of the Institutel of Automobile and Architectural Engineering is used as a dominant specialty to analyze its development status. In 2013, it built 6 online online courses for the first time (among which, 4 high-quality online courses were awarded). In 2016, it again obtained 12 university-level projects (6 high-quality online courses were awarded). The data as of November 2016 showed that the cumulative number of elective courses in the 12 courses reached 2,551, and the number of course visits totaled more than 40,000.

As a discipline-based compulsory course "Structural Mechanics" and professional basic courses "Construction Engineering Regulations" , students tend to choose the courses. Because teachers take into account professional employment requirements, teachers will guide students in teaching materials to learn reference books, norms, videos, exercises and websites related to the practice qualification exam, and share learning methods. Some teachers will combine the practice of the curriculum, share large-scale engineering cases and design software teaching, highlighting individualized learning methods, and inspire learners' interest in learning. It can be seen that online teaching can effectively display the diversity and practicality of the courses to students through online learning, and promote the integration and integration of various professional courses.

The Learning Effect is Improved Significantly and the Students' self-learning Enthusiasm is Stimulated. Students' learning autonomy needs guidance. The improvement of learning achievement depends on the change of learning methods, and the contrastive study of traditional teaching methods and the change of teaching aids on the Internet platform. Taking the "Balance of Road and Bridge Project Budget" course as an example, the elective students for the online class are 2012, 2013 and 2014 classmates of civil engineering majors. The study time is the fall semester of 2015, 2016 and 2017. The road and bridge engineering The budget is a more applied curriculum. The budget-based online course platform used in assistive teaching includes syllabus, teaching calendar, teacher information, teaching materials, coursework, and course management.

From the comparative analysis of the final grades of three consecutive students at 2012, 2013, and 2014 levels, as shown in Table 1, after online teaching aids using the online platform, grades of 
2013 and 2014 students were generally better than grades using a single traditional teaching. The average score increased by 5 to 7 points, the passing rate increased by $5 \%$, the excellent rate increased by $3 \%$ to $6 \%$, and the standard deviation of scores increased significantly. The data shows that students have a greater tendency to learn in the Internet age, and personalized education is more conducive to students' learning and mastery of knowledge. Students will not interrupt the acquisition of knowledge after the class, and students' autonomy will be improved.

Table 1 Comparison of the final scores of traditional teaching with online network teaching

\begin{tabular}{ccccccc}
\hline Grade & $\begin{array}{c}\text { Students } \\
\text { Number }\end{array}$ & $\begin{array}{c}\text { Average } \\
\text { Score }\end{array}$ & Pass Rate & $\begin{array}{c}\text { Excellent } \\
\text { Rate }\end{array}$ & $\begin{array}{c}\text { Score } \\
\text { Standard } \\
\text { Deviation }\end{array}$ & Teaching Method \\
\hline 2012 & 49 & 66.69 & $77.55 \%$ & $3.23 \%$ & 8.94 & $\begin{array}{c}\text { Traditional } \\
2013\end{array}$ \\
21 & 73.85 & $83.54 \%$ & $9.68 \%$ & 12.04 & $\begin{array}{c}\text { Traditional }+ \\
\text { online assistance } \\
\text { Traditional }+ \\
\text { online assistance }\end{array}$ \\
\hline
\end{tabular}

\section{Summary}

Information-based online teaching has been popularized in China. The online education environment is not optimistic. The teacher's R\&D lacks the enthusiasm and continuity of teaching reform due to the imbalance of cost-effectiveness. According to the status of universities, every efforts should be made to promote the advantages of policy guidance, establish advantageous majors and encourage teachers' enthusiasm. Compared with the traditional teaching, the network can improve the student pass rate and excellent rate, and promote students' interest in independent study. To maintain the virtuous operation of the network teaching environment depends on the teachers' innovative technical training and the guidance of students' learning methods.

\section{Acknowledgements}

Education Fund Project of the Education Department of Jilin Province. Dual-Invasion Application of Civil Engineering under the Background of College Entrance Examination Reform Research and Practice on the Model of Talent Training Mode (2017 Jijiao High SJJY201711)

Research on the Characteristics and Education System of Civil Engineering Dual-Innovation Applied Talents in the "Internet+" Era (2016 Jijiao High-32 SGJY201609);

Beihua University Education Fund Project. Research and Practice of Results-Oriented Project Management Professional Innovative Talents Training Program in the Background of Engineering Education Certification (XJYB2017001)

\section{References}

[1]Linmei Liang, Zhihui Luo: Open Education Research, Vol. 19 (2013) No.1, p.74-84.

[2] Xiaofeng Li,Zhonghua Wang: Chinese Distance Education,2012,p.67-70.

[3] Shuyi Xie, Yuchao Chen :China Education Informatization, 2011. p.10-14. 